\section{RKVL-318, a Root-knot Nematode- resistant Watermelon Line as Rootstock for Grafted Watermelon}

\author{
Judy A. Thies', Amnon Levi, and Jennifer J. Ariss
}

U.S. Department of Agriculture, Agricultural Research Service, U.S. Vegetable Laboratory, 2700 Savannah Highway, Charleston, SC 294145334

\section{Richard L. Hassell \\ Coastal Research and Education Center, Clemson University, 2700 Savannah Highway, Charleston, SC 29414-5334}

Additional index words. Citrullus lanatus var. citroides, Meloidogyne incognita, watermelon breeding

The Agriculture Research Service, U.S. Department of Agriculture, announces the release of 'RKVL-318', a novel germplasm line useful as a rootstock and as a genetic resource for enhancing resistance to root-knot nematodes (RKNs) in watermelon cultivars. 'RKVL-318' is derived from the wild-type watermelon Citrullus lanatus (Thunb.) Matsum. et Nakai subsp. lanatus var. citroides (Bailey) Mansf. ex Greb. (CLC) that is indigenous to southern Africa. The 'RKVL-318' plants are resistant to the southern RKN (Meloidogyne incognita), peanut RKN (Meloidogyne arenaria), and Javanese RKN (Meloidogyne javanica). The watermelon plants grafted on 'RKVL-318' rootstock had considerable yield advantage over non-grafted watermelon plants in fields infested with RKN. 'RKVL-318' should be useful in breeding programs aiming to develop RKN-resistant rootstocks for grafted watermelon or to enhance RKN resistance in watermelon cultivars. 'RKVL-318' was developed at the USDA, ARS, U.S. Vegetable Laboratory, Charleston, SC, by Dr. Judy A. Thies, Research Plant Pathologist, and Dr. Amnon Levi, Research Plant Geneticist.

\section{Origin}

Development of 'RKVL-318' began in 1999 with greenhouse and field evaluations of the U.S. PI collection of Citrullus spp. for resistance to RKN. In the greenhouse study, 20 CLC PIs showed significantly higher RKN resistance compared with all other 400 Citrullus spp. PIs evaluated, including PIs representing cultivated [C. lanatus var. lanatus $(C L L)]$ or desert-type watermelon $[C$. colocynthis $(C C)]$ (Thies and Levi, 2003, 2007). These RKN-resistant CLC PIs

Received for publication 15 Oct. 2012. Accepted for publication 8 Jan. 2014

${ }^{1}$ To whom reprint requests should be addressed; e-mail judy.thies@comcast.net. had $3 \%$ to $19 \%$ of the root system galled. In contrast, all of the $C C$ and $C L L$ PIs were highly susceptible to RKN with $73 \%$ to $100 \%$ and $32 \%$ to $100 \%$ galling, respectively. After these greenhouse observations, we selected the most resistant CLC PIs with $3 \%$ to $13 \%$ galling and performed additional greenhouse and field evaluations of these PIs during 2000 through 2011 (Thies et al., 2010). A single plant of PI482324 that exhibited high RKN resistance $(6 \%$ galling $)$ was self-pollinated. The most RKN-resistant plant was self-pollinated in the greenhouse in three successive generations to produce S4 seeds.

Table 1. Percentages of roots galled by Meloidogyne incognita, numbers of $M$. incognita eggs per gram fresh root, percentages of roots with fibrous roots, and watermelon fruit yields and numbers for 'Tri-X 313' seedless watermelon grafted on rootstocks of RKVL-318 wild watermelon rootstock, selected commercial rootstocks, and self-grafted and non-grafted 'Tri-X 313' watermelon, Charleston, SC, 2009 and 2010.

\begin{tabular}{|c|c|c|c|c|c|}
\hline \multicolumn{4}{|c|}{ Response to root-knot nematodes } & \multicolumn{2}{|c|}{ Yield } \\
\hline Rootstock accession & $\begin{array}{c}\text { Percentages } \\
\text { of roots } \\
\text { galled }^{z}\end{array}$ & $\begin{array}{c}\text { Eggs per } \\
\text { gram fresh } \\
\text { root }^{\mathrm{y}}\end{array}$ & $\begin{array}{l}\text { Percentages } \\
\text { of roots with } \\
\text { fibrous roots }\end{array}$ & $\begin{array}{l}\text { Total wt } \\
(\mathrm{kg} / \mathrm{plot})^{\mathrm{w}}\end{array}$ & $\begin{array}{l}\text { No. of } \\
\text { fruit/plot }\end{array}$ \\
\hline \multicolumn{6}{|l|}{2009 field trial } \\
\hline $\begin{array}{l}\text { RKVL } 318 \text { (Citrullus lanatus } \\
\quad \text { var. citroides) }\end{array}$ & $13 \mathrm{a}^{\mathrm{v}}$ & $16 \mathrm{a}$ & $87 \mathrm{c}$ & $29.5 \mathrm{e}$ & $12.0 \mathrm{~d}$ \\
\hline Emphasis (Lagenaria siceraria) & $86 \mathrm{~d}$ & $835 \mathrm{c}$ & $33 \mathrm{~b}$ & $17.2 \mathrm{~d}$ & $7.0 \mathrm{bc}$ \\
\hline $\begin{array}{l}\text { Strong Tosa (Cucurbita } \\
\quad \text { moschata } \times \text { Cucurbita maxima }\end{array}$ & 99 e & $3137 \mathrm{~d}$ & $35 \mathrm{a}$ & $11.6 \mathrm{a}$ & $3.0 \mathrm{a}$ \\
\hline $\begin{array}{l}\text { Tri-X } 313 \text { non-grafted } \\
\quad(\text { C. lanatus var. lanatus })\end{array}$ & $41 \mathrm{c}$ & $140 \mathrm{~b}$ & $54 \mathrm{~b}$ & $15.7 \mathrm{c}$ & $6.0 \mathrm{~b}$ \\
\hline Tri-X 313 self-grafted & $31 \mathrm{~b}$ & $91 \mathrm{~b}$ & $51 \mathrm{~b}$ & $21.5 \mathrm{de}$ & $8.0 \mathrm{bc}$ \\
\hline \multicolumn{6}{|l|}{2010 field trial } \\
\hline RKVL 318 & $40 \mathrm{a}$ & $148 \mathrm{a}$ & $55 \mathrm{~cd}$ & $19.9 \mathrm{a}-\mathrm{e}$ & $3.0 \mathrm{bc}$ \\
\hline Emphasis & $97 \mathrm{c}$ & $3950 \mathrm{c}$ & $66 \mathrm{~d}$ & $7.2 \mathrm{ab}$ & $1.4 \mathrm{ab}$ \\
\hline Strong Tosa & $96 \mathrm{c}$ & $2462 \mathrm{~b}$ & $5 \mathrm{~b}$ & $3.0 \mathrm{a}$ & $0.6 \mathrm{a}$ \\
\hline Tri-X 313 non-grafted & $96 \mathrm{c}$ & $119 \mathrm{~b}$ & $1 \mathrm{a}$ & $15.3 \mathrm{bc}$ & $2.8 \mathrm{~b}$ \\
\hline Tri-X 313 self-grafted & $76 \mathrm{~b}$ & $188 \mathrm{c}$ & $30 \mathrm{c}$ & $20.0 \mathrm{~cd}$ & $3.9 \mathrm{c}$ \\
\hline
\end{tabular}

${ }^{z}$ Data were arcsine transformed before analysis; non-transformed data are shown.

${ }^{y}$ Data were $\log _{10}(x+1)$ transformed before analysis; non-transformed data are shown.

${ }^{x}$ Root systems were rated on a $0 \%$ to $100 \%$ scale, where $100 \%=100 \%$ of root system had fibrous roots and $0 \%=$ root system had no fibrous roots

${ }^{\mathrm{w}}$ Six plants per plot $(12$ feet $\times 15$ feet $=\approx 30$ square feet per plant $)$.

${ }^{v}$ Means within a column followed by the same letter are not significantly different $(P<0.05)$ according to Fisher's protected least significant difference. Means are compared within each trial.

Reprinted with permission from Thies et al. (2015). 

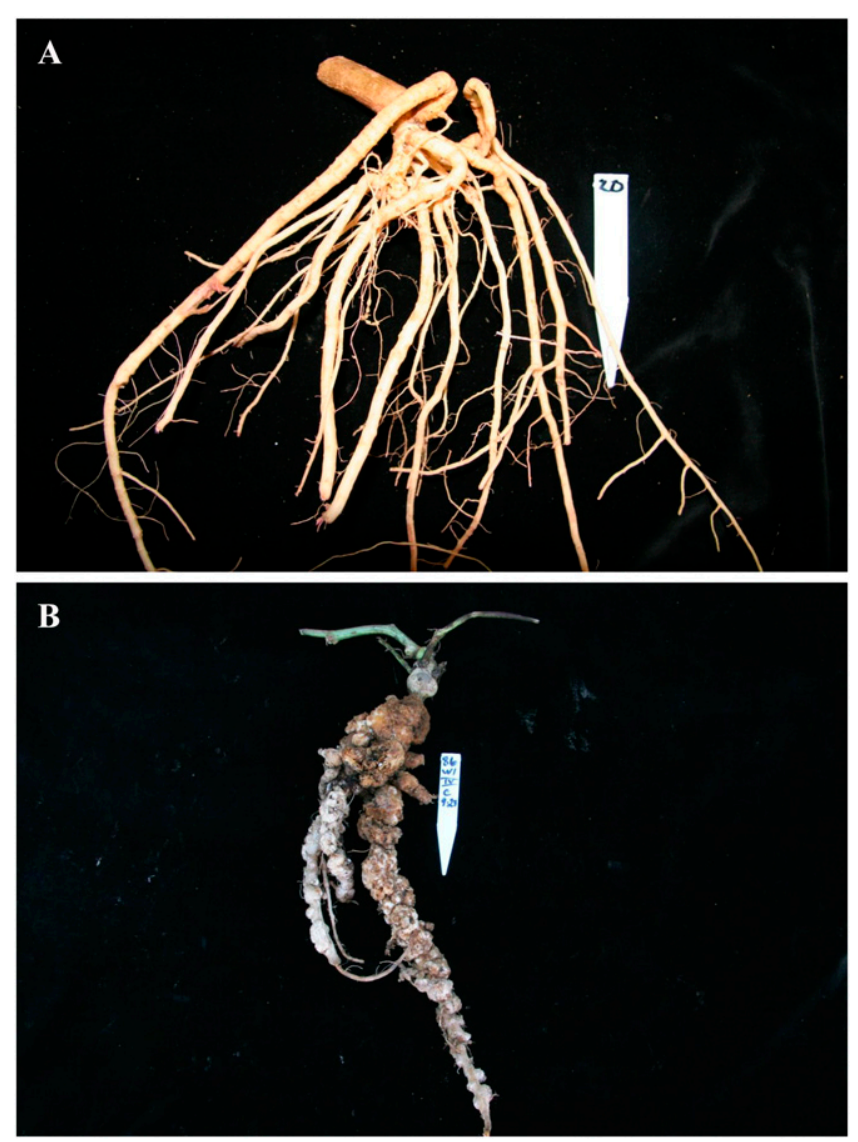

Fig. 1. (A) Root-knot nematode-resistant RKVL 318 wild watermelon rootstock root system with very minimal root-knot nematode galling. (B) Root-knot nematode-susceptible 'Emphasis' bottle gourd rootstock root system with severe RKN galling. Charleston, SC, 2010.

respectively, and an average 55\% greater than non-grafted 'Tri-X 313'.

'RKVL-318' has a runner growth habit with an intermediate leaf blade type. The 'RKVL-318' plants are andromonoecious, having male and hermaphrodite flowers. The fruits have an oblate shape with average fruit size of $20.9 \times 18.0 \mathrm{~cm}$. The rind color of mature fruits is light green with darker green stripes, which have irregular margins; average rind thickness is $2.7 \mathrm{~cm}$. The flesh color is light green to yellow with a firm texture and does not exhibit a hollow heart. 'RKVL-318' produced 1.3 fruits per plant (6.8 $\mathrm{kg}$ per fruit). Fruits are ready for harvest at $90 \mathrm{~d}$ post-planting. The seeds are moderately large and red in color.
'RKVL-318' should be useful for scientists and plant breeders interested in developing $\mathrm{RKN}$-resistant watermelon rootstocks and/or in developing watermelon breeding lines or cultivars with enhanced $\mathrm{RKN}$ resistance.

\section{Seed Availability}

Small seed samples of 'RKVL-318' are available for distribution to interested research personnel and plant breeders. Written requests for seed should be submitted to Dr. Judy Thies, U.S. Vegetable Laboratory, 2700 Savannah Highway, Charleston, SC 29414-5334. Seed of 'RKVL-318' also will be submitted to the National Plant Germplasm System where it will be available for research purposes, including the development and commercialization of new cultivars. It is requested that appropriate acknowledgment of the source be given when this germplasm contributes to research or development of a new breeding line or cultivar.

\section{Literature Cited}

Thies, J.A., J. Ariss, R. Hassell, S. Buckner, and A. Levi. 2015. Accessions of Citrullus lanatus var. citroides are valuable rootstocks for grafted watermelon in fields infested with root-knot nematodes. HortScience 50:4-8.

Thies, J.A., J.J. Ariss, R.L. Hassell, S. Olson, C.S. Kousik, and A. Levi. 2010. Grafting for management of southern root-knot nematode, Meloidogyne incognita, in watermelon. Plant Dis. 94:1195-1199.

Thies, J.A. and A. Levi. 2003. Resistance of watermelon germplasm to the peanut rootknot nematode. HortScience 38:1417-1421.

Thies, J.A. and A. Levi. 2007. Characterization of watermelon (Citrullus lanatus var. citroides) germplasm for resistance to root-knot nematodes. HortScience 42:1530-1533.

Yetisir, H., N. Sari, and S. Yucel. 2003. Rootstock resistance to fusarium wilt and effect on watermelon fruit yield and quality. Phytoparasitica 3:163-169. 